\title{
UPAYA MENINGKATKAN KETERAMPILAN GURU DALAM MENGELOLA KELAS DAN MENGAJAR KELOMPOK KECIL DAN PERORANGAN MELALUI SUPERVISI KLINIS DENGAN PENDEKATAN KOLABORATIF DI MAS NURUL HAKIM TEMBUNG DELI SERDANG
}

\author{
Julkifli \\ Dosen STKIP Budidaya Binjai
}

\begin{abstract}
ABSTRAK
Penelitian ini bertujuan untuk mengetahui peningkatan keterampilan Mengelola Kelas dan keterampilan mengajar kelompok kecil dan perorangan melalui supervisi klinis dengan pendekatan kolaboratif. Penelitian ini dilaksanakan di MAS Nurul Hakim Tembung, Deli Serdang \pm 3 bulan, mulai dari tanggal 1 Agustus s/d 24 Nopember 2018. Subjek penelitian ini adalah 3 (tiga) orang guru MAS Nurul Hakim Tembung, Deli Serdang. Objek dalam penelitian ini adalah meningkatkan keterampilan Mengelola Kelas dan Mengajar Penelitian tindakan ini menggunakan model penelitian tindakan kelas. Hasil analisis data guru dalam menerapkan keterampilan Mengelola Kelas sebagai berikut : pada saat siklus I rata-rata sebesar 67,65\% (kategori cukup) dan keterampilan Mengajar Kelompok Kecil dan Perorangan sebesar 65,96\% (kategori cukup). sehingga dilakukan bantuan berupa bimbingan kepada guru tentang bagaimana Mengelola Kelas dan Mengajar Kelompok Kecil dan Perorangan yang baik. Setelah dilakukan Tindakan Supervisi klinis, maka keterampilan Mengelola Kelas pada siklus II naik menjadi 83,16\% (kategori baik), begitu juga dengan keterampilan Mengajar Kelompok Kecil dan Perorangan pada siklus II naik menjadi $82,45 \%$. Dari paparan data tersebut dapat diketahui bahwa telah terjadi peningkatan nilai keterampilan guru di MAS Nurul Hakim Tembung, Deli Serdang dalam Mengelola Kelas dan Mengajar Kelompok Kecil dan Perorangan melalui kegiatan supervisi klinis dengan pendekatan kolaboratif, sehingga kepala Madrasah/Sekolah dan pengawas sekolah dapat menerapkan serta mengembangkan kegiatan supervisi klinis dengan lebih baik, dengan harapan kemampuan guru dalam mengajar menjadi lebih baik.
\end{abstract}

kata kunci : mengelola kelas, mengajar kelompok kecil dan perorangan, supervisi klinis pendekatan kolaboratif

\section{PENDAHULUAN}

Pendidikan merupakan hal yang paling penting dalam sebuah negara. Pendidikan juga menjadi penentu akan berkembang dan mundurnya suatu peradaban. Pendidikan yang baik akan tercipta dengan adanya evaluasi dari kegiatan pendidikan tersebut, sehingga akan terjadi peningkatan dalam kegiatan pendidikan itu sendiri. Peningkatan dari kegiatan pendidikan, akan berimbas ke semua sektor yang akan mempengaruhi maju mundurnya sebuah negara. Pendidikan di indonesia mengalami perkembangan walaupun tidak secara signifikan. Pemerintah melalui kebijakannya terus berusaha untuk mengembangkan mutu pendidikan nasional kita. Mulai dari bantuan operasional sekolah, yang bertujuan untuk membebaskan pungutan bagi seluruh siswa SD dan juga SMP dari kewajiban-kewajiban 
sekolah yang bersifat materil, serta meringankan beban biaya operasi sekolah bagi siswa di sekolah swasta (Permendikbud No 76 Tahun 2012/Juknis Bos 2013). Begitu juga tentang peraturan kementerian pendidikan dan kebudayaan tentang sertifikasi guru (Peraturan Menteri Pendidikan dan Kebudayaan Republik Indonesia Nomor 62 Tahun 2013), yang bertujuan untuk meningkatkan professionalisme guru dalam mengajar serta meningkatkan kesejahteraan kehidupan guru, sehingga berimplikasi terhadap semangat dan kegairahan guru dalam mengajar. Guru sebagai pendidik merupakan faktor penentu kesuksesan setiap usaha pendidikan. Maka dari itu pembicaraan mengenai pembaruan dan perubahan kurikulum, pengadaan alat-alat belajar, sampai pada kriteria sumber daya manusia yang dihasilkan oleh usaha pendidikan, selalu bermuara pada guru. Hal ini menunjukkan betapa pentingnya posisi guru dalam dunia pendidikan. Pendidik merupakan tenaga profesional yang bertugas merencanakan dan melaksanakan proses pembelajaran, menilai hasil pembelajaran, melakukan pembimbingan dan pelatihan, serta melakukan penelitian dan pengabdian kepada masyarakat (Undang-Undang Sistem Pendidikan Nasional No. 20 Tahun 2003, Bab XI Pasal 39 Ayat 2).

Brown, dalam Sardiman (2010) mengemukakan bahwa, tugas dan peranan guru antara lain: menguasai dan mengembangkan materi pelajaran, merencanakan dan mempersiapkan pelajaran sehari-hari, mengontrol dan mengevaluasi kegiatan siswa. tidak hanya itu, peranan guru disekolah tidak hanya sebagai transmiter dari ide, tetapi juga berperan sebagai transformer dan katalisator dari nilai dan juga sikap dari peserta didik. Kenyataan yang ada bahwa banyak dari para guru yang belum menguasai delapan ketrampilan dasar dalam mengajar, khususnya keterampilan Mengelola Kelas dan keterampilan mengadakan variasi dalam mengajar. sehingga pembelajaran yang berlangsung sering kali tidak optimal dan terkesan monoton. Oleh karena itu diperlukan supervisi (bantuan) yang bertujuan memperbaiki kelemahan guru dalam Mengelola Kelas dan mengadakan variasi dalam mengajar. salah satu bantuan yang bisa diberikan pada guru dalam mengatasi masalahnya dalam menerapkan keterampilan dasar mengajar adalah supervisi klinis. Hal ini sesuai dengan yang dikatakan muktar dan iskandar (2009:59) bahwa supervisi klinis merupakan bantuan bagi guru dalam memperbaiki dan meningkatkan keterampilan mengajarnya. Begitu juga Pidarta (2009) yang berpendapat bahwa supervisi klinis adalah suatu proses bimbingan yang bertujuan untuk membatu 
mengembangkan profesional guru/calon guru, khususnya dalam penampilan mengajar, berdasarkan observasi dan analisis data secara teliti dan obyektif sebagai pegangan untuk perubahan tingkah laku mengajar.

Richard Waller dalam Purwanto (2004) mendefinisikan bahwa supervisi klinis adalah supervisi yang difokuskan pada perbaikan pengajaran melalui siklus yang sistematis mulai dari tahap perencanaan, pengamatan, dan analisis intelektual yang intensif terhadap penampilannya mengajar sebenarnya dengan tujuan untuk mengadakan modifikasi yang rasional. Dalam pelaksanaannya supervisi klinis memiliki pendekatan yang perlu diterapkan agar supervisi yang dilakukan dapat membantu guru memperbaiki sikap dan perilakunya dalam mengajar. pendekatan dalam supevisi klinis antara lain : (1) direktif, (2) non-direktif dan (3) kolaboratif, (yasaratodo, 2014). Pendekatan kolaboratif adalah pendekatan yang dilakukan dengan konsep kerjasama antara supervisor dan guru.

Supervisi klinis memiliki keunggulan sebagai berikut : supervisi klinis, yaitu supervisi yang prosedur pelaksanaanya lebih ditekankan kepada mencari sebab-sebab atau kelemahan yang terjadi didalam proses belajar mengajar, dan kemudian secara langsung pula diusahakan bagaimana cara memperbaiki kelemahan atau kekurangan tersebut. Berdasarkan pengalaman peneliti yang telah melakukan pelatihan supervisi klinis terhadap 3 orang guru di MTs Al-Hasyimiyah Tebing Tinggi, Tanggal 3 September s/d 23 Oktober 2015, bahwa supervisi klinis sangat tepat digunakan dalam mengatasi masalah guru dalam menerapkan keterampilan dasar dalam mengajar. Permasalan utama dalam penelitian ini adalah kurangnya guru dalam menerapkan keterampilan Mengelola Kelas dan Mengajar Kelompok Kecil dan Perorangan. penelitian ini dilaksanakan untuk mengetahui apakah pelaksanaan supervisi klinis dengan pendekatan kolaboratif dapat meningkatkan keterampilan guru dalam Mengelola Kelas. Dan untuk mengetahui apakah pelaksanaan supervisi klinis dengan pendekatan kolaboratif dapat meningkatkan keterampilan guru dalam mengajar kelompok kecil dan perorangan.

\section{METODE}

Penelitian ini adalah penelitian tindakan sekolah. Penelitian Tindakan Sekolah dilaksanakan dengan strategi siklus yang berangkat dari identifikasi masalah yang dihadapi 
kepala sekolah atau pengawas sekolah. Dimulai dari penyusunan rencana tindakan, pelaksanaan tindakan, observasi tindakan, dan refleksi.

Rangkaian kegiatan berurutan mulai dari rencana tindakan sampai dengan refleksi disebut satu siklus penelitian. Penelitian tindakan sekolah ini diadaptasi dari penelitian tindakan model Kemmis dan Taggart. Setiap siklus terdiri dari empat tahap, yakni (1) Perencanaan tindakan, (2) Pelaksanaan tindakan, (3) observasi, dan (4) analisis refleksi, Kemmis dan Taggart (Nusa Putra : 2014). Subjek penelitian adalah 9 orang guru di MAS Nurul Hakim Tembung, Deli Serdang Sumut. Subjek ditentukan dengan cara purposive, yaitu teknik penentuan sampel dengan pertimbangan tertentu (Sugiono, 2008).Teknik pengumpulan data dalam penelitian ini adalah : (1) observasi, (2) dokumentasi, dan (3) lembar observasi. Teknik analisis data dalam penelitian ini menggunakan teknik persentase, yang mana data dibandingkan sebelum dan sesudah diadakannya kegiatan supervisi klinis dengan pendekatan kolaboratif.

\section{HASIL DAN PEMBAHASAN}

Hasil Observasi Keterampilan Mengelola Kelas dan Mengajar Kelompok Kecil dan Perorangan Pada Siklus I

Deskripsi nilai keterampilan guru dalam Mengelola Kelas mulai dari yang tertinggi dan yang terendah dapat dilihat pada grafik dibawah ini :

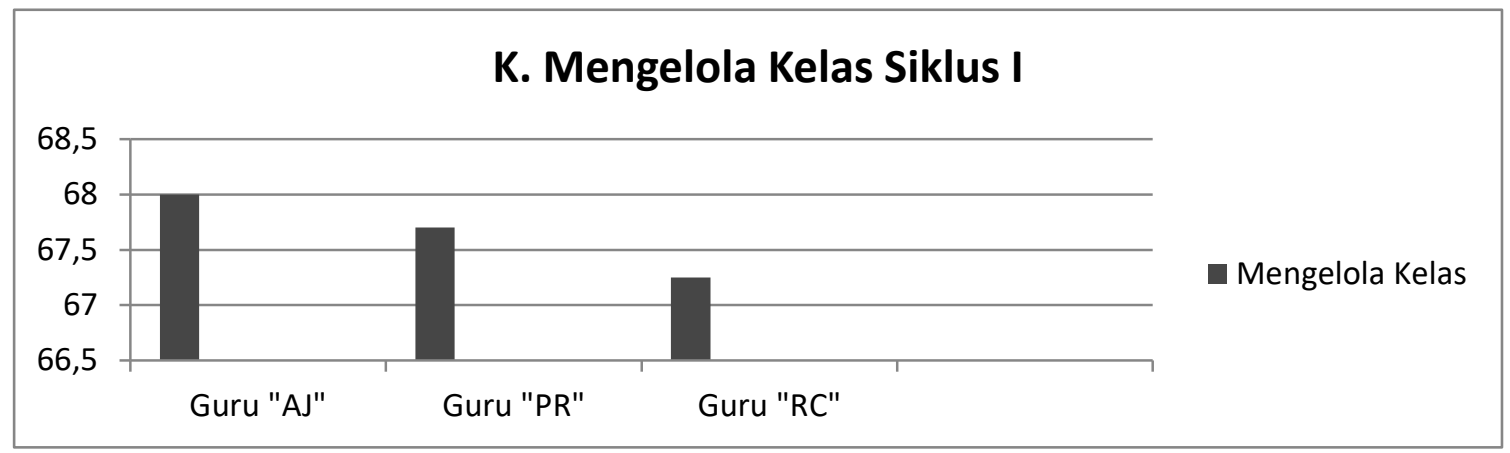

Gambar 1. Hasil observasi keterampilan guru dalam Mengelola Kelas

Deskripsi nilai keterampilan guru dalam Mengajar Kelompok Kecil dan Perorangan mulai dari yang tertinggi dan yang terendah dapat dilihat pada grafik dibawah ini : 


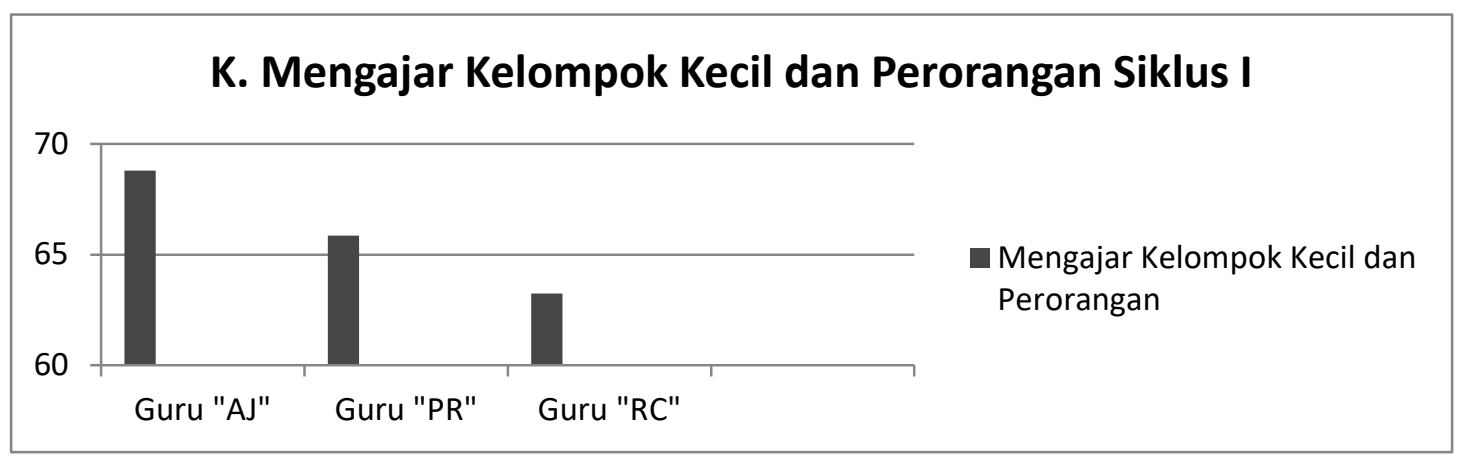

Gambar 2. Hasil observasi keterampilan guru dalam Mengelola Kelas

Pada siklus I keterampilan guru dalam Mengelola Kelas mengalami peningkatan. guru AJ sebelumnya 53,00 (kategori kurang) meningkat menjadi 66,00 (kategori cukup). guru PR sebelumnya 52,00 (kategori kurang) meningkat menjadi 67,70 (kategori cukup). Guru RC sebelumnya 50,58 (kategori kurang) meningkat menjadi 67,25 (kategori cukup). Begitu juga dengan keterampilan mengadakan variasi. Guru AJ sebelumnya 55,90 (kategori kurang) meningkat menjadi 68,80 (kategori cukup). Guru PR sebelumnya 53,85 (kategori kurang) meningkat menjadi 65,85 (kategori cukup). Guru RC sebelumnya 51,25 (kategori kurang) meningkat menjadi 65,96 (kategori cukup).

\section{Rekapitulasi Hasil Keterampilan Mengelola Kelas Dan Mengajar Kelompok Kecil dan Perorangan Guru Pada Siklus I}

Berdasarkan data hasil dari rekapitulasi pada siklus I menunjukkan bahwa masih terdapat kelemahan guru dalam melaksanakan keterampilan Mengelola Kelas dan mengadakan variasi dalam mengajar. ini dapat dilihat dari persentase rata-rata tiap guru pada rekapitulasi hasil keterampilan Mengelola Kelas dan Mengajar Kelompok Kecil dan Perorangan pada tabel 2 diatas. Sehingga siklus II dilaksanakan dengan mengacu pada pola siklus pada model Kemmis dan Taggart.

\section{Hasil Observasi Keterampilan Mengelola Kelas dan Mengajar Kelompok Kecil dan Perorangan Pada Siklus II}

Deskripsi nilai keterampilan guru dalam Mengelola Kelas mulai dari yang tertinggi dan yang terendah dapat dilihat pada grafik dibawah ini : 


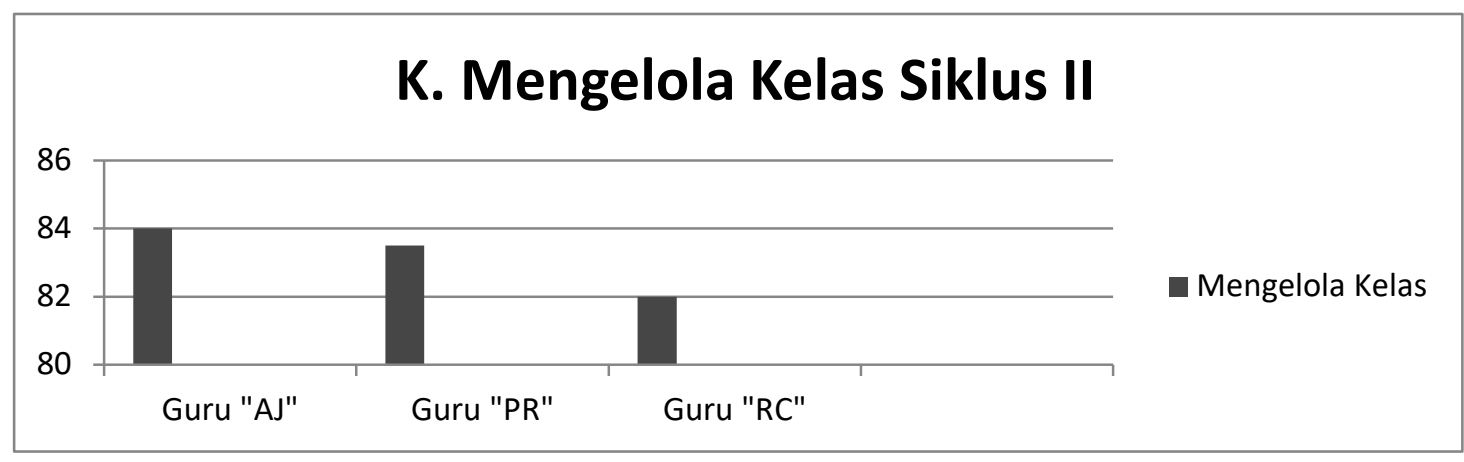

Gambar 3. Hasil observasi keterampilan guru dalam Mengelola Kelas pada siklus II

Deskripsi nilai keterampilan guru dalam Mengajar Kelompok Kecil dan Perorangan mulai dari yang tertinggi dan yang terendah dapat dilihat pada grafik dibawah ini :

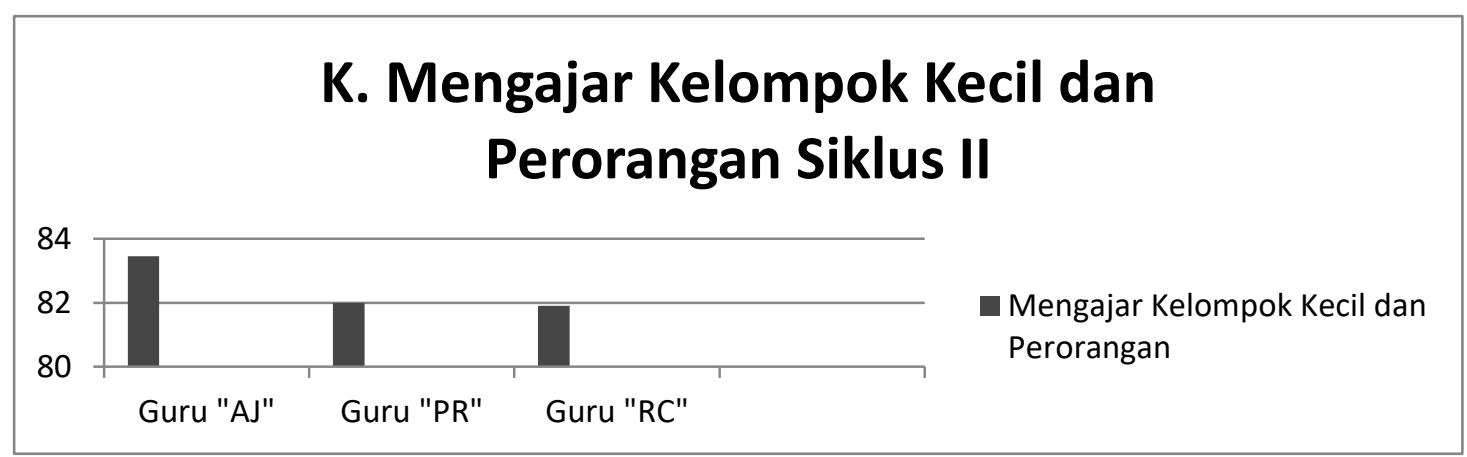

Gambar 4. Hasil observasi keterampilan guru dalam Mengajar Kelompok Kecil dan

Perorangan pada siklus II

Pada siklus I keterampilan guru dalam Mengelola Kelas mengalami peningkatan. guru AJ sebelumnya 68,00 (kategori cukup) meningkat menjadi 84,00 (kategori baik). guru PR sebelumnya 67,70 (kategori cukup) meningkat menjadi 83,50 (baik). Guru RC sebelumnya 67,25 (kategori cukup) meningkat menjadi 82,00 (baik). Begitu juga dengan keterampilan mengajar kelompok kecil dan perorangan. Guru AJ sebelumnya 68,80 (kategori cukup) meningkat menjadi 83,45 (baik). Guru PR sebelumnya 65,85 (kategori cukup) meningkat menjadi 82,00 (kategori baik). Guru RC sebelumnya 63,25 (kategori cukup) meningkat menjadi 81,90 (kategori baik). 


\section{Rekapitulasi Hasil Keterampilan Mengelola Kelas Dan Mengajar Kelompok Kecil dan Perorangan Guru Pada Siklus II}

Berdasarkan data hasil dari rekapitulasi pada siklus II menunjukkan bahwa terjadi peningkatan pada keterampilan guru dalam Mengelola Kelas dan Mengajar Kelompok Kecil dan Perorangan. dapat dilihat bahwa persentase rata-rata keterampilan guru dalam Mengelola Kelas dan Mengajar Kelompok Kecil dan Perorangan berkategori baik. Sehingga siklus berikutnya tidak dilanjutkan.

\section{PEMBAHASAN}

Peningkatan dari professionalitas guru dalam mengajar amatlah penting. Bantuan untuk meningkatkan profesionalitas guru dalam mengajar sangat dibutuhkan terlebih bantuan yang bersifat kontinuitas atau berkesinambungan. Salah satu bantuan yang bisa diberikan kepada guru guna meningkatkan professionalitas mereka dalam mengajar adalah supervisi klinis. Hal ini seperti yang dikemukakan oleh Arikunto (2002:373) bahwa supervisi merupakan bantuan untuk guru memperkecil ketidaksesuaian (kesenjangan) antara tingkah laku mengajar yang nyata dengan tingkah laku mengajar yang ideal. supervisi berusaha memperkecil kesalahan-kesalahan guru dalam proses pembelajaran menjadi lebih baik (ideal). Begitu juga Sagala (2012:248-249) mengatakan bahwa supervisi klinis berguna untuk meningkatkan keterampilan mengajar guru dikelas dan merupakan kunci untuk meningkatkan kemampuan professional guru, sehingga dapat menunjang pembaharuan pendidikan serta untuk memerangi kemerosotan pendidikan terutama dimulai dengan cara mengajar guru dikelas.

Hasil observasi pada siklus I menunjukkan bahwa telah terjadi perubahan dalam keterampilan guru dalam mengajar serta keterampilan guru dalam Mengajar Kelompok Kecil dan Perorangan. tentunya ini ditandai dengan bantuan klinis yang dilakukan supervisor kepada guru baik dalam mempersiapkan rencana pelaksanaan pembelajaran (RPP) maupun bantuan tentang penggunaan keterampilan dalam Mengelola Kelas dan mengadakan variasi secara baik dan benar. Siklus II merupakan perbaikan dan juga peningkatan keterampilan guru dalam Mengelola Kelas dan Mengajar Kelompok Kecil dan Perorangan dari siklus I. yakni pelaksanaan supervisi klinis yang berkonotasi dengan bimbingan dan bentuan yang diberikan kepada guru untuk meningkatkan keterampilan 
dasar mengajar mereka serta meningkatkan kemampuan guru dalam merencanakan kegiatan pembelajaran dengan baik dan benar. Pada siklus II diberikan tindakan klinis berupa bantuan tentang beberapa komponen dari keterampilan Mengelola Kelas guru yang masih memiliki kelemahan khususnya dalam pemberian tekanan, penyajian, pengorganisasian dan balikan. Begitu juga dilakukan tindakan klinis berupa bantuan tentang beberapa komponen keterampilan Mengajar Kelompok Kecil dan Perorangan guru khususnya dalam gaya mengajar, alat bantu mengajar, dan variasi interaksi. Adapun outcome yang diharapkan dari pelaksanaan supervisi klinis dengan pendekatan kolaboratif adalah meningkatnya pemahaman dan kemampuan guru mengenai keterampilan dalam Mengelola Kelas dan mengadakan variasi dalam mengajar. sehingga peserta didik akan lebih memahami pelajaran yang disampaikan oleh guru.

\section{SIMPULAN}

Berdasarkan analisis dan pembahasan yang telah dijelaskan pada bagian sebelumnya, maka dapat disimpulkan bahwa : (1) Terjadi peningkatan keterampilan Mengelola Kelas guru MAS Nurul Hakim Tembung, Deli Serdang dengan rata-rata peningkatan keterampilan Mengelola Kelas dari siklus I sebesar 67,65 (kategori cukup), pada siklus II sebesar 83,16 (kategori baik). (2) Terjadi peningkatan keterampilan Mengajar Kelompok Kecil dan Perorangan guru MAS Nurul Hakim Tembung, Deli Serdang dengan rata-rata peningkatan keterampilan Mengajar Kelompok Kecil dan Perorangan dari siklus I sebesar 65,96 (kategori cukup), pada siklus II sebesar 82,45 (kategori baik). Dengan rata-rata peningkatan tiap siklus I dan II guru SS sebesar 13,81\%, guru WS sebesar 14,64 \% dan guru ZS sebesar 14,53\%. Pelaksanaan supervisi klinis dengan pendekatan kolaboratif dapat meningkatkan keterampilan Mengelola Kelas dan Mengajar Kelompok Kecil dan Perorangan guru MAS Nurul Hakim Tembung, Deli Serdang.

\section{REFERENSI}

Arikunto, S. 2004. Dasar-dasar supervisi, Yogyakarta : Rineka Cipta 
Kemmis. S. \& Mc Tagart, R. 1982. The action reseach planner. Victoria, Australia : Deakin University Press

Muktar dan Iskandar. 2009. Orientasi baru supervisi pendidikan, Jakarta : Gaung Persada Press

Pidarta, Made. 1992. Pemikiran Tentang Supervisi Pendidikan. Jakarta: Bumi Aksara.

Purwanto, Ngalim. 2004. Administrasi dan supervisi pendidikan. Bandung : Remaja Rosda Karya

Saardiman A.M. 2010. Interaksi dan Motivasi Belajar Mengajar. Jakarta: Rajawali Pers.

Sagala, Syaiful. 2012. Administrasi Pendidikan Kontemporer. Bandung: Alfabeta.

Sugiyono. 2008. Metode Penelitian Kunatitatif Kualitatif dan R\&D. Bandung : Alfabeta.

Wau, Yasarotodo. 2014. Profesi Kependidikan. Deli Serdang : Unimed Press 